\title{
Traitorous Identities in Chimamanda Adichie's Americanah and Half of a Yellow Sun
}

\author{
Hyginus Eze
}

\begin{abstract}
The figure of the traitor is old in Nigeria literary tradition. The traitor is present in earliest generation of Nigerian novels, predominantly as a cultural turncoat, who has alienated himself or herself from the indigenous cultural system to show allegiance to the colonial master and his invading culture and ways. In Chinua Achebe's Things Fall Apart, Okoli, the new convert into Christianity is an example.
\end{abstract}

Keywords - Americanah, Half of a Yellow Sun.

\section{THE TRAITOR: THE LIZARD THAT RUINED HIS OWN MOTHER'S FUNERAL}

... the cock that crows in the morning belongs to one household but his voice is the property of the neighbourhood (Achebe Anthills 122)

The figure of the traitor is old in Nigeria literary tradition. The traitor is present in earliest generation of Nigerian novels, predominantly as a cultural turncoat, who has alienated himself or herself from the indigenous cultural system to show allegiance to the colonial master and his invading culture and ways. In Chinua Achebe's Things Fall Apart, Okoli, the new convert into Christianity is an example. By killing 'the sacred python' (Things 129) Okoli not only leagues with the colonial master against his own people, but also becomes an agent of corrosion of the indigenous ways. So also are the overzealous new Christian converts 'who had gone into the village and boasted openly that all the gods were dead and impotent and that they were prepared to defy them by burning all their shrines' (Things 124). In Achebe's Arrow of God the traitor is emblematised by Mr GoodCountry and Oduche, both cultural renegades, who are referred to variously as the "the outsiders who choose to weep louder than the owners of the corpse' (Arrow 60), or 'the lizard that ruined his own mother's funeral' (Arrow 60). Mr GoodCountry, now a missionary himself, wants a root-and-branch attack on the indigenous culture of his people. Similarly, Oduche causes moral outrage by imprisoning the sacred python in his school box, an act of betrayal against the community, but particularly against his father, Ezeulu, who sent him to school with specific instruction to learn about the white man; in fact, as he put it 'to join these people and be my eyes there' (Arrow 55). It should be pointed out that the sacred python is not just an animal among the

Hyginus Eze, Ph.D Researcher, University of Aberdeen Scotland United Kingdom. people, considering the amount of homage accorded it, but something symbolic of the people's world-view, a cultural insignia around which the people construct their socio-cultural life. Accordingly, its imprisonment is symbolically an attempt to suffocate the indigenous culture.

In these works, therefore, the traitor is a traitor precisely because he is a double agent, embodying two opposing positions, hence he is dangerous. The traitor has doublebarrelled view-points: he is schooled in the native system, but his allegiance is to another camp, an opposing camp, as it were. Accordingly, he has his back turned on the community, betraying the secrets of his people to the outsider. He is, in fact, leading the charge against his own people. In the case of the new converts in both Things Fall Apart and Arrow of God their affiliation with the colonialist imperils the people. For one thing, the new converts are already chiselled in the native ways, so their joining forces with the white man makes the people all the more vulnerable to the onslaught on the native culture by the foreign ways. For example, in one of the confrontations between the missionary and the indigenous people in Things Fall Apart, one of the Christians says to $\mathrm{Mr}$ Kiaga, the white man, 'The village has outlawed us .... The bell-man announced it last night. But it is not our custom to debar anyone from the stream or the quarry' (Things 129). The new converts are being indoctrinated into the new religion, but they are also armed with information about the inner structures and working of the indigenous system. They are informants, as it were, tipping off the white man, and helping him to outmanoeuvre the people and their tradition. Clearly then, the original figure of the traitor in Nigerian novel is that of a negative figure despised by his people for abetting an alien culture in an invasive assault on the native customs and tradition.

\section{II.TRAITOROUSNESS IDENTITIES: THE ONE WHOSE VOICE IS THE PROPERTY OF THE NEIGHBOURHOOD}

The representation of the traitor in Nigerian novels seems to have made an about-turn, beginning from the latter novels of Achebe, especially in Anthills of the Savannah. In Anthills the 'traitor' gains a positive value as someone standing with the community. As in the earlier texts, the traitor still typifies 'multiple positioning' (Val Plumwood 206). He is 'someone with a view from both sides' (205). But unlike in the earlier texts, the 'traitor' appropriates his multiple positioning, no longer to expose his people to assault but to advance the 
interest of the common people. Hence the traitor becomes traitorous, that is, someone with traitorous identities. Such are the figures of Ikem Osodi and Chris Oriko of Achebe's Anthills. Both Ikem and Chris are long-standing friends of General Sam, the Head of State, and occupy influential positions in General Sam's government. Ikem is the Editor of the National Gazette, while Chris is the Minister of Information and member of cabinet. Their proximity to power, notwithstanding both Ikem and Chris side with the masses, eventually paying the ultimate price in defence of the common people. For example, through Ikem's bonding with Elewa, his barely educated girl-friend, and sympathetic integration with taxi drivers and common people, through his rejection of the trimmings of office such as a chauffeur, he exemplifies a liquidation of class boundaries as well as embodies a deconstruction of the scalar calibration of human beings, in terms of superior/inferior. As traitorous identities, what makes both Ikem and Chris powerful is that while they are ostensibly part of the oppressor group, but they are actually standing with the masses as they are in the forefront of the "call for the total dismantling of the grotesque world in which [oppression] grows - and flourishes' (Anthills 138).

However, it is in third-generation Nigerian novels that the figure of the traitor emerges fully as someone with traitorous identities, someone with multiple perspectives, the one "with a view from both sides' (Plumwood). More importantly, thirdgeneration Nigerian novels portray traitorousness as a positive value, and as a dismantling of oppression from an insider position. In these novels the traitorous character is acutely aware of the place of class and power in the colonisation of public wealth, and embodies a fluidification of the class divide in the expropriation of public resources. In third-generation Nigerian novels, the traitorous individual is himself an elite, but he or she is in sympathy with the underclass and wants to dismantle elite privileges as they pertain to the appropriation of the general wealth. In other words, the traitorous character 'belongs' to the dominant ideology by virtue of his status as an elite or capitalist, but aligns with the ideology of the dominated other in a bid to strip power of its mystifications and make way for a more equalitarian society. The traitorous one highlights the blind-spots of power to revolutionary consciousness. The consequence, therefore, is that traitorousness sheds off its negative value as treachery or perfidy to gain a positive value, referring to the insider, who is animating revolutionary consciousness against his own ilk. Plumwood explains:

What makes such traitorous identities possible is precisely the fact that the relationship between the oppressed and the 'traitor' is not one of identity, that the traitor is critical of his or her own 'oppressor' group as someone from within that group who has some knowledge of its working and its effects on the life of the oppressed group. It depends on the traitor being someone with a view from both sides, able to adopt multiple perspectives and locations [] (205).
The traitorous individual epitomizes ideological selfcontradiction. As Eagleton has remarked individuals, values and systems can be 'internally self-contradictory, serving [opposing] social ends' (Eagleton 148).

Obinze and Ifemelu of Adichie's Americanah and Olanna and Kainene of Half of a Yellow Sun also by Adichie typify in their careers traitorous identities. Obinze who is from an upper middle class family loses his father at seven. The mother, a university lecturer and self-assertive woman, has a reputation on campus for standing up to men. After a series of frustrations, not least his failed attempt to settle in the United Kingdom, Obinze makes a fortune in real estate business through the help of the tycoon, crisply known as Chief.

But from an early age Obinze has established himself as an outsider and a non-conformist to the dominant values of his social group. For example, in school his friends attempt to railroad him into a relationship with Ginika, who they describe as 'just a sweet girl' (Americanah 60), and 'the queen God made for you [Obinze) if you are ready to work for it' (Americanah 56). On the other hand, Ifemelu, Ginika's friend is considered unsuitable for Obinze because she is 'too much trouble. She can argue. She can talk. She never agrees' (Americanah 61). Obinze's response to this match-making causes every one consternation: 'I'm not interested in girls that are too nice' (Americanah 61). The result is that Obinze settles for Ifemelu, the girl with too much trouble. That same day Obinze confesses to Ifemelu the reason for the unintended chemistry between them 'You looked like the kind of person who will do something because you want to, and not because everyone else is doing it' (Americanah 61). In other words, Obinze falls for Ifemelu because he sees her as an independent-minded person, a social outsider of a sort, and rejects Ginika who belongs to the same class as himself. Little wonder that Ifemelu is gnawed by fear of their social incompatibility, and admits to herself that Ginika is a better match for Obinze:

... suddenly Ifemelu thought how much Ginika and Obinze had in common. Ginika's house at the University of Lagos, the quiet bungalow, the yard crowned by bougainvillea hedges, was perhaps like Obinze's house in Nsukka and she imagined Obinze realising how better suited Ginika was for him (Americanah 67).

By breaching the bourgeois value that places premium on dynasty alliance to align with Ifemelu who is much beneath him in social ranking, Obinze is not only bridging social boundaries, but also adopting 'multiple perspectives and locations' as well as being 'critical of his own group' (Plumwood 206). By the fact of being born into the family with the 'quiet bungalow' and 'yard crowned by bougainvillea' he is ineluctably a bearer of elite value, but by aligning with the lower class he is constructing for himself a value system in opposition to the one his social group has pre-appointed for him. Viewed from the position of elite values Obinze has 
failed to produce himself as 'a reflector of the norm' (Akwanya and Anohu 123). Significantly, what for Ifemelu highlights the incompatibility between her and Obinze is the fact that they are groomed in different social circumstances. Ifemelu's apartment block is described in unflattering terms 'it was cramped, the kitchen walls blackened by kerosene fumes, and she was embarrassed when her school friends came to visit ...' (Americanah 49). Added to this is the fact that the parents cannot even afford the rent, so the landlord occasionally creates a scene about it, 'It is now three months! I am still waiting for my money!' (Americanah 48/49)

Now an adult Obinze's multiple positionality gains more social relevance. Having made a fortune, Obinze is now, as he himself phrases it 'in the game' (Americanah 435). As a real estate businessman he has properties all over Nigeria as well as 'property in Dubai' (Americanah 432) and he is 'looking into buying property in Miami' (Americanah 434). The result is that Obinze now mixes with the high and mighty. During the party at Chief's place the conversation centres around the appropriation social infrastructures:

'How is your child? Has she started school?' Mrs Akin Cole asked.

'You must send her to the French school. They are very good, very rigorous. Of course they teach in French but it can only be good for the child to learn another civilized language, since she already learns English at home'.

Okay, ma I'll look at the French school,' Kosi said.

The French school is not bad but I prefer Sidcot Hall. They teach the complete British curriculum,' said another woman, whose name Obinze had forgotten.

'Oh, yes, Sidcot Hall,' Kosi said. 'It's already on top of my list because I know they teach the British curriculum'.

Obinze would ordinarily not have said anything at all, just watched and listened, but today, for some reason, he said, 'Didn't we all go to primary school that taught Nigerian curriculum?'

The women looked at him; their puzzled expressions implied that he could not possibly be serious. And in some ways, he was not. Of course he, too, wanted the best for his daughter. Sometimes, like now he felt like an intruder in his new circle .... (Americanah 28/29).

The conversation that is going on here constitutes a 'discursive formation' a concept that Eagleton explains as a 'set of rules which determine what can be and must be said from a certain position' (1994:195). There is a kind of takenfor-grantedness in this discourse: the characters are a circle of elite, and there is an unspoken understanding that their social positions entitle them to the best the city can offer. The shock engendered by Obinze's contribution is in the fact that he inaugurates a discourse that organises a different set of principles. He introduces values that are antagonistic to those of the elite class. Obinze's position implies a de-stratified society in which the Nigerian curriculum would cater for the educational needs of every segment of society, a democratisation of social space, as it were. Accordingly, Obinze produces himself as an infiltrator in this group. Strictly speaking it is an inside-outside positioning. For one thing, Obinze is necessarily an embodiment of bourgeois values. After all he confesses that he would, like every other person in the circle, send his own daughter to the elite school. In other words he claims the privileges of his social position. To this extent he is an insider and ineluctably a vector of elite values. But he is also an outsider to the group in his implied advocating of classlessness, where the home-spun educational curriculum will serve every stratum of society. Hence he draws 'puzzled expressions' from his 'ilk' who are uncomfortable with his class levelling tendencies.

Obinze's vantage location as an elite, an insider gives him a huge revolutionary potential since he views society from the underbelly, and is launching attack from the inside. $\mathrm{He}$ is a traitor to the privileged class in that, although he is a member of the elite class, he has nothing but contempt for the values shared by the group. Obinze is betraying the values of privilege that mark out elitism as well as spotlighting it to revolutionary consciousness. He is manifesting traitorous identities, slipping between multiple identities, now an insider, now an outsider. He expropriates his elite position to challenge and highlight oppression, and to make a case for restructuring society in favour of the disempowered. Hence he embodies socio-economic democratisation and classlessness.

The traitor has 'shifting subjectivities' Alice Curry 40). The narrator says about Obinze, 'When he was younger, he had admired people with moneyed childhoods and foreign accents, but he had come to sense an unvoiced yearning in them, a sad search for something they would never find' (Americanah 29). His position as a member of the elite enables him not only to gain exclusive insight into the world of the privileged but also vouchsafes him multiple views as well as 'multiple identification' (Curry 40). He is able to see the emptiness, pretensions and the tragedy constitutive of the upper-class, a social group in 'a sad search for something they will never find' (Americanah 29). The consequence of Obinze's deepseated contempt for the bourgeois class is that he uses every available opportunity to belittle privilege and class pretensions. He describes Chief as a 'fop, with his air of fussy grooming' and Chief and his friends as 'three guffawing, knowing men' (Americanah 24).

Characters with traitorous identities are equally evident in Adichie's Half of a Yellow Sun in the careers of Olanna and Kainene. Both Olanna and Kainene are daughters to Chief Ozobia, a business magnate who makes a fortune through sharp practices in government contract. Like Obinze, Olanna and Kainene are embodiments of bourgeois values, having enjoyed upper-class privileges from childhood. For example, Kainene's and Olanna's rooms are called 'flats' because of the 'reams of space' as well as the general decoration: 'the tan furniture, the wall-to-wall burgundy carpeting that cushioned the feet' (Half 48). In Port Harcourt, where Kainene oversees her father's business, her place is described thus: 'tastefully 
mismatched furniture, wood carvings, muted paintings of landscapes, rounded sculptures. The polished floors had a woody scent' (Half 99). Kainene has a private suite in her father's Zobis Hotel, and the suite overlooks 'the palm trees by the swimming pool' and also overlooks Heathgrove, a British school. Both Olanna and Kainene had their foundational education at Heathgrove, a British school in Nigeria that is described as 'iniquitously expensive' (Half 81), and their tertiary education was in England. But in spite of all these privileges, Olanna and Kainene always demonstrate that they are aligned with the underclass. For example, Olanna demands that their houseboy, Maxwell, be accorded some dignity. On the occasion that the family host the Finance Minister, Chief Okonji, Olanna is unhappy that nobody acknowledges the effort of the houseboy:

None of them thanked Maxwell. Olanna wished they would; it was a simple thing to do, to acknowledge the humanity of the people who served them. She had suggested it once; her father said he paid them salaries, and her mother said thanking them would give them room to be insulting .... (Half 45$)$.

As far as Chief Ozobia is concerned there is no room for intercourse between the family members and Maxwell; it is an exchange relation between the labour power (commodity) of the houseboy and wage. In other words the labour power of the houseboy exists independent of his person and it is this labour that Chief Ozobia purchases with wage. Luckảcs uses different concepts to explain this phenomenon: thingification, rationalisation, reification (1971). There is no difference between Mrs Ozobia and the husband: their idioms are underlain by a capitalist frame of thinking. On the other hand, Olanna's discourse hacks back to a pre-capitalist society in which the commodity form has not interpenetrated and concealed 'the relation between people' (83).

Fundamentally, Olanna is a class-leveller. She turns down Chief Okonji's invitation for a 'cocktail at Ikoyi Hotel' because, as she phrases it, 'I will be doing a St Vincent de Paul charity drive tomorrow' (Half 48). But it is in respect of social infrastructures that Olanna's desire for a de-stratified society is best expressed. Her mother is shocked when she turns her back on the extravagant comfort Lagos affords her to settle for the relatively bare comfort of middle class life at Nsukka: 'But will you be comfortable there?' Her mother said comfortable with a faint shudder, and Olanna smiled because her mother had Odenigbo's basic university house in mind, with its sturdy rooms and plain furniture and uncarpeted floors' (Half 50). In other words both Olanna and Kainene are realised as ideologically self-contradictory. They were born into affluence and opulence, and they exploited their privileged social condition to ascend the social ladder, Olanna becoming a university lecturer, and Kainene, a business manager. But they are constructing a value system different, indeed antagonistic to the one in which they have been schooled from their childhoods.

There seems to be a difference between Obinze of
Americanah and Olanna and Kainene of Half, in terms of characters whose careers are personify multiple identification. Obinze remains in an ideological tug of war until the end of the text, a situation exemplified in the following lines: 'Obinze felt repulsion and longing; he pitied them [the bourgeois class], but he also imagined being like them' (Americanah 25). The only sign of break, at best a partial break with bourgeois life, is his severing from his wife, Kosi, who represents for him an unrestrained conformity with upper class values and pretensions, to settle with Ifemelu who shares his revulsion with the make-believe life of the oligarchs. In the case of Olanna and Kainene, the civil war provides an opportunity for them to make a volte face and to align decidedly with the less privileged.

As soon as the civil war breaks out Chief and Mrs Ozobia manage to secure four flight tickets to escape to London. But Olanna and Kainene refuse to budge, preferring to suffer wartime deprivations like every other person. Olanna remembers her last meeting with her mother, where she is desperately trying to convince her daughters to come along with them, 'the four places are paid for', she said, climbing into the car, holding tightly to her jewellery-filled bag' and 'Olanna waved until the Range Rover drove past the compound gates' (Half 233). As the war raged Olanna and Odenigbo are forced to relocate to Umuahia and move into a place described thus:

There was nothing normal about the house. The thatch roof and the cracked, unpainted walls bothered Ugwu, but not as much as the cavernous pit latrine in the outhouse with a rusting zinc sheet drawn across it to keep flies out (Half 241).

In spite of this reduced social station, Olanna still manages to run a school in her compound for displaced families, improvising for the barest essentials. For example, 'Ugwu arranged three benches on the veranda for Olanna's class and two by the compound entrance for Mrs Mokelu's' and Ugwu is also seen 'arranging his blackboard against a tree stump' (Half 355). After the family lose their accommodation in this squalor they move to a place much worse: 'The bathroom floor was slimy with too much dirt washed off too many bodies, and the toilet was thick with the smells of strangers' (Half 397). In the same way, Kainene, Olanna's younger sister declines to escape to London with the parents, preferring, like her elder sister, to involve herself in efforts targeted at alleviating the suffering of the masses caught up in the war. Kainene runs a refugee camp in a place that 'was a primary school before the war. The buildings looked faded, most of the once-white paint peeled off. Some refugees were standing outside' (Half 421). The refugees themselves present a macabre picture, 'About twelve people were lying on bamboo beds, on mats, on the floor. Not one of them reached out to slap away the fat flies' (Half 422). It is clear then that whereas Olanna and Kainene are born into a brutally, exploitative, uncaring capitalist family, they manage to construct for themselves socialist values that focus on public welfare rather than on acquisition. As the war roars on and 
things get harder, Kainene is initiating one welfarist programme after another. For example, after the blockade makes it impossible for food supplies to come to war-torn Biafra from sympathetic countries, she begins a programme tagged 'Plant Our Own' in which the refugees are meant to support their food needs through their own farming efforts. Ultimately, Kainene disappears while trading across enemy lines to buy food stuffs for the refugees.

These values of sacrifice and struggle for the good of the collective run counter to the capitalist values Olanna and Kainene are born into. In other words there is a gap between the welfarist values they construct and manifest and stand for and the capitalist values they inherited by virtue of their births. The values they inherited from their society are at variance with the ones they profess. Olanna and Kainene express these values most clearly in their attitude to social issues, in their readiness to break away from the glamour and comforts offered by the elite space they are born into to seek the company of the underprivileged. In terms of revolutionary potentiality Olanna and Kainene have more significance than Obinze of Americanah. In the final analysis Obinze is not able to resolve the tug of war orchestrated by his multiple identification. Although Obinze's opening up of cracks to expose the Achilles heel of elite power is in itself revolutionary, it may be said that he remains sucked in by the capitalist values of his society, acquiring properties both in Nigeria and abroad. Indeed even the collapse of his marriage dovetails with the capitalist framework of thinking in that he privileges his personal emotions and interests over and above the overall interest of his family members.

Conversely, Olanna and Kainene epitomise the fluidification of social ranking, highlighting that social station is not a fixed and unvarying realm of the privileged and the underprivileged. The career of the two characters signify a liquidation of the binary of superiority and inferiority which organises class relations in their society. And this is important for revolutionary consciousness. More, Olanna and Kainene also represent the possibility of social evolution from capitalism to welfarism. All these values are embodied in their willingness to settle into a social space different from the one they inherited.

However, Olanna and Kainene still have common grounds. Like Obinze of Americanah Olanna and Kainene's identification with the poor does not end at offering them support and encouraging welfarist values; it also includes efforts to unclasp the iron-grip of oppression. For example, Olanna makes a pointed caricature of Chief Okonji, the Finance Minister, 'She looked at his neck, settled into rolls of fat, and imagined him prying the folds apart as he bathed' (Half 48). On another occasion Olanna 'felt vaguely sickened at how her hands sank into his [Chief Okonji's] soft chest' (Half 49). The two go farther than Obinze in their anti-elite discourse. Whereas Obinze's anti-elite discourse is couched in gestures, concealed attacks and suggestive statements, Olanna and Kainene engage in a pointed attack against the grasping elite, beginning with their father. For example, Olanna defends their driver who was caught stealing rice from the family:

My father and his politician friends steal money with their contracts, but nobody makes them kneel to beg for forgiveness. And they build houses with their stolen money and rent them out to people like this man and charge inflated rents that make it impossible to buy food (Half 269).

This is a poignant description of a vicious circle in which the politicians colonise social space and instrumentalise it to impoverish the all-ready poor. Chief Ozobia and the politicians appropriate public wealth and turn it against the masses in a kind of double manoeuvre in which the social effort of the people is masked as personal effort and used to orchestrate their oppression. Olanna also brings out the double standard in a choreographed justice system in which the politicians and the bourgeois class place themselves above the law and cover up their crimes, while the misdemeanours of the underclass are highlighted and severely punished. Just as is the case in Americanah, there is something 'traitorous' in the multi-perspectival position of Olanna. Being an elite herself she has insight into the malpractices of the politicians and capitalists, but having constructed values that fly in the face of elitism, she is able to mount attack from the inside. Hence Olanna and Kainene are traitorous figures.

Another way in which traitorous characters attempt to subvert elite power in the novels is through body-imaging. Through their description of the elite, traitorous figures imply that there is a correlation between body image or physiognomy and character type. More importantly, by de-valuing the elite characters through body imaging, traitorous characters not only demystify power, but also become a conduit for a potential revolution.

\section{PhysiognOMIC DEgRAdATION AND SUbVERSION OF POWER}

It does appear that the most powerful thing about power is the atmosphere of awe and hypnotism it engenders among the masses. Power creates a sacred distance between the powerful and the powerless. Power emits enthralment, it enchants and enraptures which is one of the means by which it sustains itself and maintains a chokehold on the de-privileged. Part of the logic of Adichie's texts seems to be that there is nothing immanently superior about the powerful. This kind of logic is important in animating revolutionary consciousness as it highlights that much of the power that emanates from powerful people is a mist Power wraps around itself. One of the goals of these texts, therefore, is to demystify the mystery of Power by imaging the characters who are occupying authority-positions as less than average people In other words, these texts, through traitorous characters, critique the 'unsubtle cowering of [the poor] in the presence of the rich' (Americanah 25). Traitorous characters puncture the scalar gradation of human beings, in terms of superiority and inferiority, and they are convincing because they speak from an insider-position. For 
example, through Uju's closeness to The General, the latter's coarseness, his ill-breeding and boorishness is exposed:

The General had yellowed eyes, which suggested to Ifemelu a malnourished childhood. His solid, thickset body spoke of fights that he had started and won, and buck-teeth that gaped through his lips made him seem vaguely dangerous. Ifemelu is surprised by the gleeful coarseness of him. 'I am a village man!' he said happily, as though to explain the drops of soup that landed on his shirt and on the table when he ate, or his loud burping afterwards. He arrived in the evenings ... his $\mathrm{ADC}$, at an obsequious pace behind him, brought his briefcase and put it on the dining table (Americanah 79).

The text makes a comment on Power by paralleling The General's vulgarity with the slavish attention accorded him by his ADC, who follows at an 'obsequious pace behind him'. There is nothing inherently superior about The General, yet he exudes enormous power being a General in a military Government. The passage also spotlights a society in which, as Yeats writes, 'The best lack all conviction, while the worst/ Are full of passionate intensity ('The Second Coming' lines 7 - 8). The passage indicts the society, where the passport to authority-position is the ability to intimidate, menace and crush anything on the way. But it is the presence of the traitorous individual, Uju, that vouchsafes the public the vulgar side of Power, deflecting attention from the enchanting mesmerism of Power. By putting on display The General's crassness, by showing the clumsiness of those in positions of authority Uju becomes an agent of potential revolution. Uju is an informant reporting on the mean side of Power to the public. She warms herself into the innards of Power, while standing with the common people. In the presence of The General 'Aunty Uju would laugh, suddenly girlish and pliant' (Americanah 80); and her adroitness earns her the confidence of The General. The conversation between Uju and Ifemelu is illustrative of how much she is trusted with information about what happens behind the scenes: 'If I tell you what these people do, eh,' Aunty Uju would say to Ifemelu.... 'Their real stories are not even in the magazines. Oga has the real gist' and 'Then she would talk about the man who had sex with a top general to get an oil bloc' (Americanah 79), and on and on, all the time enunciating the vile side of Power. The place of the traitorous individual is an inside-outside position. The 'traitor' is simultaneously within and without. The traitorous individual occupies a co-terminous position. As an insider the traitorous character blends with Power, but as an outsider she is dynamising revolutionary consciousness.

Such is the place of Obinze in the same Americanah by Adichie. Although he is a member of the elite, Obinze describes himself an outsider in the elite circle. We are told that 'Sometimes, like now, he felt like an intruder in his new circle, of people who believed that the latest schools, the latest curriculums, would ensure the wholeness of their children' (Americanah 29). Obinze feels nothing short of revulsion towards the burnished surfaces and class posturing of his new circle. They are class-obsessed people, who exteriorise attidunisations to plug up their deficiencies and insecurities. As a member of the elite who is contemptuous of the pretensions of his class, Obinze becomes a crack in the wall through which the public can have a glimpse into the real world of the elite, the real world unburnished by make-believe. Accordingly, Obinze describes his new circle as people 'enmeshed in insecurities' and speaks of Mrs Akin Cole, a member of the group as a 'certain kind of middle-aged woman, dried up by disappointment, blighted by bitterness, the sprinkle of pimples on her forehead smothered in heavy foundations' (Americanah 29). Obinze describes Chief as a 'smallish man' and as 'something of a fop, with the air of fussy grooming: nails manicured and shiny, black velvet slippers at his feet, a diamond cross around his neck' (Americanah 24).

By exposing the emptiness and the affectations of the powerbrokers, both Uju and Obinze are putting Power on display and making those who exercise power vulnerable. What makes traitorous characters a real threat to the oligarchs is that, being part of the elite, they view Power from its underbelly and operate like informants. These traitorous individuals are ostensibly on the side of the elite, but their allegiance is to the masses. Their goal is, therefore, to dislodge the foothold of Power by demystifying it. It is through the unflattering imaging of the elite, through the portrayal of their vulgarness that these characters are 'sowing the seeds of revolution, the portents of dissolution of an incompetent oligarchy' (Achebe 1988:115).

Similarly, Olanna and Kainene of Adichie's Half of a Yellow Sun also emphasise body image in order to sow the seeds of discord between the oligarchy and the masses, and in that way to engender revolutionary consciousness. For example, Olanna makes a pointed caricature of Chief Okonji, the Finance Minister: 'She looked at his neck, settled into rolls of fat, and imagined him prying the folds apart as he bathed' (Half 48). On another occasion Olanna 'felt vaguely sickened at how her hands sank into his [Chief Okonji's] soft chest' (Half 49). There are other third-generation Nigerian novels that attempt to animate revolution through an unfavourable imaging of the elite. For instance, in Sefi Atta's Everything Good Will Come Sheri, Brigadier Hassan's girlfriend, describes him as 'Brigadier Big Belly' (Everything 315). Through physiognomic degradation, Sheri is taking away the spell-binding clout of power and tilling the ground for revolution to overtake tyrannous patriarchy. Equally traitorous is Sergeant Okoro of Chris Abani's Graceland, who is an 'authority figure' (Graceland 256), yet he is aiding Maroko residents to mobilise against an insensitive Government as well as leaking classified information to the people. It is clear, therefore, that by 'denying sympathetic attractiveness to the [oligarchs these traitorous figures are] exposing [them] in the fullness of time to the harsh tenets of revolutionary justice' (Achebe 115).

In terms of heroic scale, Olanna and Kainene of Adichie's 
Half of a Yellow Sun out-weigh Obinze of Americanah. Obinze is operating like an informant, whispering to the public about the ill-practices of the oligarchs, while at the same time refusing to let go the perks of privilege. But instead of the punch and parry approach of Obinze, Olanna and Kainene not only dismiss elite privileges to identify with the underclass, but also confront Power headlong, openly challenging their father, Chief Ozobia and the Finance Minister, Chief Okonji both of whom iconise the grasping oligarchs. Put in another way, Olanna and Kainene are able to resolve the moral tug of war that results from their multiple identification by siding with the underprivileged, but Obinze lacks this kind of heroism.

To sum up, traitorous characters have important consequences for revolutionary consciousness. For one thing these characters tend to sign-post that class is not a fixed realm of social life but alterable. What is more, traitorous characters not only raise the flag against social malpractices, but they also expose the Achilles heels of Power by highlighting the emptiness and crassness of the elite. In other words, the multiple identification of these characters flag the fact that there is nothing sealed about the status quo. It should be noted that other contemporary Nigerian novels represent traitorous characters, albeit in a more problematic way. For instance, Eugene Achike of Adichie's Purple Hibiscus would be a travesty of the kind of characters we have been presenting. While using Standard, his media outlet, to confront state power, he himself embodies brutal power. Similarly, $\mathrm{Mr}$ Bakare of Attah's Everything is furious about the government, and he is even arrested for anti-establishment campaigns, but he underpays the staff in his chamber. A similar distortion of the traitorous figure is glimpsed in Helon Habila's Waiting for an Angel, where Mr James is using his Dial, also a media outfit, to speak to power, but tries to abscond at the first sign of trouble. These characters lack the stature of the characters identified as ideologically self-contradictory because, to all intents and purposes, they are either unable to sustain a struggle against Power or they still represent the values and principles they purport to be fighting. 